\title{
PENGARUH INOVASI PRODUK TERHADAP PENINGKATAN KINERJA UMKM OT APPAREL
}

\author{
Ela Diana Saputri ${ }^{1}$, Della Putri Satiya Ningtyas ${ }^{2}$, Nanik Kustiningsih ${ }^{3}$ \\ ${ }^{1-3}$ Program Studi Akuntansi, STIE Mahardhika, Surabaya \\ 1eldis802@gmail.com, ${ }^{2}$ della06putri06@gmail.com, ${ }^{3}$ nanik@ stiemahardhika.ac.id
}

\begin{abstract}
In Indonesia, many UMKM have opened businesses in the fashion sector, one of which is screen printing shirts. Screen printing shirts have become a target for someone to open a business today. So, OT Apparel made screen printing shirts using a DTG (Direct to Garment) printer machine. The main objective of this research is to develop product innovation to improve the performance of UMKM OT Apparel. The problem to be studied is testing the effect of product innovation on OT Apparel performance. By looking at the market share that currently has a lot of competition, entepreneurs have to come up with product innovations to attract the attention of potential consumers. The research method used is a qualitative method with a case study approach. Data collection using the observation method. Based on the results of data analysis, making an innovation, can improve the performance of UMKM OT Apparel. Always follow developments so that the design that are made can be liked by many people. Apart from product innovation, marketing strategies are also needed in orded minimize competitiveness. Therefore OT Apparel continues to improve performance and create the latest product innovation designs.
\end{abstract}

Keywords : Product Innovation, Performance, UMKM

\begin{abstract}
ABSTRAK
Di Indonesia banyak UMKM yang membuka usaha di bidang fashion, salah satu nya kaos sablon. Kaos sablon sudah menjadi sasaran seseorang untuk membuka usaha saat ini. Maka OT Apparel membuat kaos sablon dengan menggunakan mesin printer DTG (Direct to Garment). Tujuan utama penelitian ini adalah mengembangkan inovasi produk untuk meningkatkan kinerja UMKM OT Apparel. Permasalahan yang akan diteliti yaitu menguji pengaruh inovasi produk terhadap kinerja OT Apparel. Dengan melihat pangsa pasar yang saat ini banyak persaingan menyebabkan pengusaha harus memunculkan inovasi-inovasi produk agar menarik perhatian calon konsumen. Metode penelitian yang digunakan adalah metode kualitatif dengan pendekatan studi kasus. Pengumpulan data menggunakan metode observasi. Berdasarkan hasil analisis data, membuat suatu inovasi dapat meningkatkan kinerja UMKM OT Apparel. Selalu mengikuti perkembangan agar desain yang dibuat dapat disukai banyak orang. Selain dengan inovasi produk, strategi pemasaran juga diperlukan agar meminimalisir daya saing. Maka dari itu OT Apparel terus meningkatkan kinerja dan membuat desain inovasi produk terbaru.
\end{abstract}

Kata Kunci: Inovasi Produk, Kinerja, UMKM

\section{PENDAHULUAN}

Indonesia merupakan negara yang berperan aktif dalam bidang bisnis. Di tahun 2020, diketahui bahwa wabah virus Covid-19 sudah menyebar ke seluruh negara termasuk Indonesia sehingga menyebabkan perubahan diberbagai aspek. Salah satu bisnis yang terdampak dari adanya Covid-19 adalah bisnis fashion. Dengan melihat banyak persaingan bisnis saat ini tentunya harus memperhatikan inovasi produk untuk menarik perhatian konsumen. Inovasi dapat diartikan suatu proses pembuatan untuk menciptakan sesuatu yang baru ada beberapa tujuan untuk melakukan inovasi diantaranya yaitu meningkatkan kualitas produk, menciptakan produk baru dan meningkatkan efisiensi produk tersebut. Secara tidak langsung melakukan inovasi akan membuat semakin kompetitif sehingga dapat menambah nilai pada suatu perusahaan.

Dalam mencapai target bisnis selalu ada peran dari sumber daya manusia yang sangat berpengaruh terhadap pencapaian yang 
diinginkan. Kualitas kinerja seseorang salah satu faktor dalam bisnis agar tetap berkembang. Kinerja adalah hasil kerja seseorang dalam melaksanakan tugasnya dengan penuh tanggung jawab untuk mencapai target perusahaan. Oleh karena itu, diperlukan evaluasi dari Manajemen untuk melihat keahlian seseorang yang kompeten. Faktor yang mempengaruhi kinerja karyawan adalah tanggung jawab, kedisiplinan, komunikasi, efektifitas dan efisiensi waktu. Dari faktor tersebut ketika seseorang sudah melakukan semua faktor dengan baik maka akan menghasilkan tujuan yang diinginkan.

Menurut UU No 19 Tahun 2002, Inovasi diyakini sebagai kegiatan atau aktivitas yang dapat mengembangkan nilai praktis dengan konsep ilmu pengetahuan ke dalam produk ataupun proses produksinya.

Dalam dunia fashion terdapat gaya berpakaian yang berubah-ubah setiap tahunnya, tetapi tidak berpengaruh pada kaos. Saat ini kaos sablon banyak diminati oleh masyarakat sekitar. Dengan kemajuan teknologi saat ini sablon digital sudah ada, Sablon kaos digital adalah teknik mencetak foto atau gambar ke permukaan kaos dengan menggunakan mesin printer DTG (Direct to Garment). Jenis kaos yang digunakan OT Apparel adalah cotton combed 30s dan terdapat berbagai macam warna. Dengan menggunakan sablon digital yang memiliki kelebihan hasil cetak gambar bagus, ketajaman warna yang tinggi, lebih hemat dalam biaya dan waktu dalam proses, tidak memakan biaya menggunakan transfer paper dengan biaya produksi yang rendah produk kaos ini dapat terjual dengan harga terjangkau.

\section{TINJAUAN PUSTAKA}

Penelitian terdahulu bertujuan untuk mengetahui secara jelas penelitian yang akan digunakan dengan penelitian yang ada, sehingga terhindar dari kesamaan dari peneliti sebelumnya. Pada penelitian ini penulis mencantumkan dua penelitian terdahulu.

Yanti Heryanti (2020) melakukan penelitian tentang Inovasi Produk Sandal Wanita Prodior di Kampung Ciponyo Kelurahan Mangkubumi Kecamatan Mangkubumi Kota Tasikmalaya. Teknik pengumpulan data yang digunakan penelitian ini menggunakan studi kepustakaan dan teknik lapangan seperti wawancara, observasi dan dokumentasi. Hasil penelitian ini disimpulkan bahwa inovasi produk dan orientasi pasar berpengaruh positif baik secara simultan ataupun parsial, dimana perusahaan mendesain produk sesuai keinginan pelanggan dapat bertahan di tengah persaingan.

Adijati Utaminingsih (2016) yang berjudul Pengaruh Orientasi Pasar, Inovasi, dan Kreativitas Strategi Pemasaran Terhadap Kinerja Pemasaran Pada UKM Kerajinan Rotan di Desa Teluk Wetan, Welahan, Jepara. Teknik penelititian ini menggunakan analisis regresi berganda. Hasil penelitian menunjukkan bahwa ada pengaruh signifikan antara orientasi pasar, inovatif dan kreativitas pemasaran strategis terhadap kinerja pemasaran usaha kecil menengah rattan handycraft rotan di desa Teluk Wetan, Welahan, Jepara.

Anthony Leonardo Jonathan (2018) melakukan penelitian tentang Analisis Tahapan Inovasi Produk Pada PT Karyayudha Tiaratama. Berdasarkan hasil penelitiannya menunjukkan bahwa inovasi produk merupakan pengembangan dari produk yang sudah ada di PT Karyayudha Tiaratama, agar dapat bersaing dan mengikuti perubahan perkembangan pasar.

Menurut penelitian Nanik

Kustiningsih dan Bambang Tjahjadi (2020) 
dengan judul Pengaruh Mediasi dari Kinerja Proses Bisnis pada Strategi Inovasi-hubungan kinerja biaya: Studi Kasus Industri manufaktur di Provinsi Jawa Timur, Indonesia. Berdasarkan penelitiannya bahwa manajer perlu meningkatkan strategi inovasi dan kinerja bisnis untuk mengoptimalkan kinerja biaya perusahaan.

\section{METODOLOGI PENELITIAN}

Metode penelitian yang digunakan dalam penelitian ini adalah metode penelitian kualitatif. Penelitian kualitatif adalah proses penelitian dengan menyusun asumsi dasar dan aturan berpikir dalam meneliti. Didalam penelitiannya peneliti tidak menggunakan angka atau mengumpulkan data. Penelitian Deskriptif adalah metode penelitian yang menggambarkan data atau objek kemudian dianalisis berdasarkan kenyataan dan memecahkan permasalahan setelah itu memberikan informasi dari masalah tersebut. Menurut Creswell, penelitian kualitatif adalah proses memahami masalah sosial berdasarkan metodologi berbeda, dimana peneliti menganalisa dan menyusun gambaran hasil penelitian secara fakta atau sesuai fakta di lapangan. Penelitian kualitatif merupakan penelitian untuk menjelaskan kualitas dari pengaruh sosial yang tidak dapat diukur melalui pendekatan kuantitatif (Saryono 2010). Penelitian kualitatif bertujuan untuk menganalisis peristiwa yang terjadi dilapangan dalam konteks ruang dan waktu secara alami.

Sumber data penelitian adalah subjek dari data yang didapat subjek dalam penelitian ini adalah kinerja UMKM OT Apparel sebagai sumber peneliti yang terkait dengan penelitian yang dilakukan. Objek penelitian adalah permasalahan yang akan diteliti. Dalam penelitian ini, objek penelitiannya adalah pengaruh inovasi produk. Teknik pengumpulan data menggunakan pendekatan studi kasus. Metode pengumpulan data menggunakan metode observasi. Penelitian pendekatan studi kasus adalah untuk meneliti suatu masalah dengan cara mengumpulkan informasi yang akan diolah sehingga dapat terselesaikan. Penelitian studi kasus bertujuan untuk mengambil pelajaran yang didapat, tetapi banyak yang menunjukkan adanya perbedaan menghasilkan teori dan kebenaran yang baru.

Yang pertama adalah pemilihan kasus dalam penelitian kualitatif. Peneliti menjadikan lingkungan sebagai dasar untuk melihat inovasi produk dapat membuat kinerja OT Apparel semakin inovatif dalam menciptakan sebuah ide. Peneliti melanjutkan pengumpulan data melalui observasi. Peneliti dapat menyesuaikan cara penngumpulan data dengan masalah yang diteliti. Setelah data terkumpul, peneliti dapat melakukan analisa data secara kronologis sesuai data yang dilakukan peneliti saat di lapangan, Kemudian penyaji melakukan perbaikan atau penyempurnaan, Yang terakhir penyaji melakukan penulisan laporan, laporan tersebut harus ditulis secara komunikatif agar dapat dibaca dan dipahami oleh masyarakat dan peneliti dapat mempertanggungjawabkan atas hasil penelitian sebuah studi kasus. Lokasi penelitian berada di JL. KH. Abu Sufyan Timur RT 15 RW 04, Kalanganyar, Sedati-Sidoarjo.

\section{HASIL DAN PEMBAHASAN}

Berdasrkan hasil penelitian diketahui bahwa inovasi produk mempengaruhi kinerja OT Apparel guna untuk meningkatkan hasil penjualan. Inovasi produk selain digunakan untuk menarik perhatian customer dapat juga digunakan untuk meningkatkan kinerja perusahaan, secara tidak langsung tim akan berkreativitas untuk menciptakan sebuah 
inovasi produk dengan melihat kondisi pasar saat ini. Produk kaos dari UMKM OT Apparel ini belum dikenal oleh masyarakat sekitar, maka dari itu OT Apparel menciptakan sebuah desain dengan inovasi inovasi baru agar dikenal masyarakat Indonesia. Untuk mencapai visi dan misi, OT Apparel harus memegang kunci strategi untuk menarik perhatian calon konsumen. Dengan mengikuti perkembangan, kami melihat sesuatu yang viral untuk dijadikan konsep dalam inovasi desain sablon kaos.

Hal tersebut bertujuan untuk menarik perhatian, Beberapa faktor yang mempengaruhi inovasi produk yaitu kompetensi sumber daya manusia yang bertanggung jawab dalam melakukan strategi inovasi, memiliki jaringan system informasi yang baik sehingga dapat menciptakan produk dengan kualitas tinggi dan mampu mengidentifikasi konsumen secara tepat, memiliki waktu inovasi yang tepat agar mencapai target sasaran sesuai yang diinginkan. UMKM OT Apparel sangat memperhatikan kualitas produk dan ketepatan waktu.

\begin{tabular}{ll}
\multicolumn{2}{c}{ Berdasarkan } \\
hasil analisis data & Mempertahankan \\
keneliti, tema yang Produk
\end{tabular} diangkat dalam pembuatan inovasi sebuah produk saat ini adalah “Among Us". Among Us adalah permainan yang dirilis pada tahun 2018 tetapi di tahun 2020
Gambar 1 Kerangka Pemikiran Sumber : Data Olahan Peneliti 2020 kesetiaan pelanggan. Setelah itu, kami melakukan strategi pemasaran di beberapa sosial media seperti Instagram, Whatsapp dan komunikasi secara langsung antar satu sama lain.

\section{KESIMPULAN}

Dari hasil penelitian diatas, maka dapat disimpulkan peneliti bahwa inovasi produk selain digunakan untuk menarik perhatian customer dapat juga digunakan untuk meningkatkan kinerja perusahaan. Secara tidak langsung tim akan berkreativitas untuk menciptakan sebuah inovasi produk dengan melihat kondisi pasar saat ini.

Produk kaos dari UMKM OT Apparel ini belum dikenal oleh masyarakat sekitar, maka dari itu OT Apparel menciptakan sebuah desain dengan inovasi-inovasi baru agar dikenal masyarakat Indonesia. Terdapat faktor yang mempengaruhi inovasi produk yaitu kompetensi sumber daya manusia yang

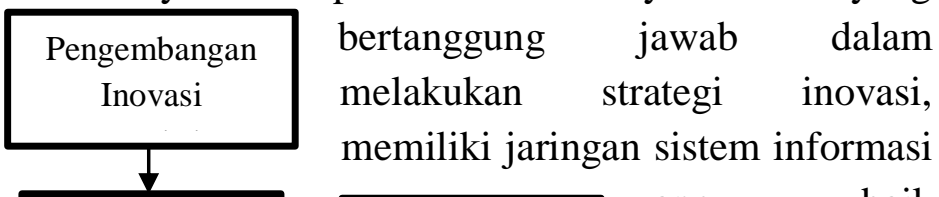
game ini tengah naik daun. Berbagai karakter yang lucu dan unik dengan beragam warna membuat UMKM OT Apparel tertarik untuk membuat desain dalam produk ini. Dalam menciptakan sebuah inovasi diperlukan adanya kerja sama yang baik antar tim. Hasil penelitian dari proses menciptakan ide sampai dengan tahap barang jadi, kami target sasaran sesuai yang diharapkan. Tema yang diangkat dalam pembuatan inovasi produk saat ini adalah "Among Us".

\section{DAFTAR PUSTAKA}

Creswell, John W. 2010. Research Design : Pendekatan Kualitatif, Kuantitaif, Mixed. melakukannya dengan baik demi menjaga 
Heryanti, Y. 2020. Inovasi Produk Sandal Wanita Prodior Di Kampung Ciponyo Kelurahan Mangkubumi Kecamatan Mangkubumi Kota Tasikmalaya. JAK PUBLIK (Jurnal Administrasi dan Kebijakan Publik). Vol. 01. No. 01.

Jonathan, A.L. 2018. Analisis Inovasi Terhadap Produk pada PT Karyayudha Tiaratama. Agora, Vol. 6. No. 2.

Kustiningsih, Nanik.,\& Tjahjadi, B. (2020). Pengaruh mediasi kinerja proses bisnis pada strategi inovasi-hubungan kinerja biaya: studi kasus industry manufaktur di Provinsi Jawa Timur Indonesia. Jurnal International Manajemen Kinerja Bisnis, 21 (3), 346-362.

Saryono. 2010, Metode Penelitian Kualitatif, PT. ASlfabeta, Bandung. (https://www.autoexpose.org/2019/06/ definisi-metode-penelitiankualitatif.html, diakses 23 November 2020).

Utaminingsih, A. 2016. Pengaruh Orientasi Pasar, Inovasi dan Kreativitas Strategi Pemasarah Terhadap Kinerja Pemasaran pada UKM Kerajinan Rotan Di Desa Teluk Wetan, Welahan, Jepara. Media Ekonomi dan Manajeman. Vol. 31. No. 02

Undang-Undang No 19 Tahun 2002. 